\title{
ANALISIS PERKEMBANGAN MORAL ANAK SD/MI
}

\author{
Yayuk Kusumawati \\ Institut Agama Islam (IAI) Muhammadiyah Bima \\ Email : yayukalkhansa@gmail.com
}

\begin{abstract}
Abstrak
Tulisan artikel ini bertujuan untuk meninjau perkembangan moral anak SD/MI. Pada sikap dan perilaku moral tersirat nilai-nilai yang dianut berkaitan dengan sesuatu yang dikatakan benar, patut dan seharusnya terjadi. Ada nilai-nilai yang perlu dipertahankan, ada yang diasimilasikan kearah kemajuan atau perubahan progresif, tetapi ada juga yang berubah atau bergeser karena berbagai factor yang mempengaruhinya. Perkembangan moral berkaitan dengan atauran dan konvensi tentang apa yang harus dilakukan anak dalam interaksi dengan orang lain. Pada saat anak telah memasuki sekolah dasar, anak-anak serius mulai mengekspresikan ide lebih obyektif keadilan. Oleh karena itu, perkembangan moral anak SD/MI harus diperhatikan, bahwa dalam proses pembelajaran di pendidikan moral sekolah diberikan kepada siswa disesuaikan dengan perkembangan mereka. Jenis penelitian yang digunakan dalam penulisan ini adalah penelitan kepustakaan (Library Research), yaitu serangkaian penelitian yang berkenaan dengan metode pengumpulan data pustaka, atau penelitian yang digali melalui beragam informasi kepustakaan seperti buku, ensiklopedi, jurnal ilmiah, koran, majalah, penelitian terdahulu dan dokumen.

Kata Kunci : Analisis Perkembangan, Moral Anak, SD/MI
\end{abstract}

\section{PENDAHULUAN}

endidikan bertujuan bukan hanya untuk membentuk manusia yang
cerdas otaknya dan terampil dalam melaksanakan tugas, namun
diharapkan menghasilkan manusia yang memiliki moral, sehingga menghasilkan warga negara excellent. Oleh karena itu pendidikan pendidikan tidak semata-mata mentransfer ilmua pengetahuan kepada peserta didik, tetapi juga mentransfer nilai-nilai moral dan dan nilai-nilai kemanusiaan yang bersifat universal. Dengan transfer moral bersifat universal, diharapkan peserta didik dapat menghargai kehidupan orang lain tercermin dalam tingkah laku serta aktualisasi diri, semenjak usia SD hingga kelak dewasa menjadi warga negara yang baik.

Dalam kenyataannya manusia Indonesia (khususnya anak-anak remaja) disaat ini, kurang memperhatikan moral yang tercermin dari perilaku tidak menghormati nilai-nilai kemanusiaan seperti seperti 
tawuran remaja, kurang menghormati orang tua, kurang menaati normanorma keluarga, hidup tidak disiplin. Terlebih pada masa globalisasi manusia indonesia cenderung berperilaku keras, cepat, akseleratif dalam menyelesaikan sesuatu, dan budaya instan. Manusia dipaksa hidup seperti robot, selalu berada pada persaingan tinggi (konflik) dengan sesamanya, hidup bagaikan roda berputar cepat yang membuat manusia mengalami disorientasi meninggalkan norma-norma universal, menggunakan konsep machiavelli (menghalalkan segala cara) mementingkan diri sendiri dan tidak memiliki moral yang baik, tidak menghargai, peduli, mengasihi, mencintai sesamanya.

Dengan diberikannya pendidikan moral bagi anak SD diharapkan dapat merubah perilaku anak, sehingga peserta didik jika sudah dewasa lebih bertanggung jawab dan menghargai sesamanya dan mampu menghadapi tantangan jaman yang cepat berubah. Disinilah pentingnya nilai-nilai moral yang berfungsi sebagai media transformasi manusia indonesia agar lebih baik, memiliki keunggulan dan kecerdasan diberbagai bidang; baik kecerdasan emosional, kecerdasan sosial, kecerdasan spiritual, kecerdasan kinestika, kecerdasan logis.

Moralitas dibangun berdasarkan cinta. Jika kita membangun ikatan dengan anak berdasarkan kasih sayang, kita dapat mempengaruhi mereka. Selanjutnya, dunia ini banyak memberi mereka contoh buruk, contoh yang kita berikan akan memberi bekas yang lebih dalam dan terus berpengaruh.

\section{TINJAUAN TEORITIS}

\section{Konsep Moral}

Moral berkenaan dengan perilaku baik atau buruk pada seseorang. Pendidikan SD tidak sekedar bertujuan untuk menjadikan peserta didik menjadi manusia yang cerdas, tapi juga manusia yang baik.

Moral berasal dari kata latin "mores" yang berarti tatacara, kebiasaan dan adat. Perilaku sikap moral Perilaku sikap moral berarti perilaku yang sesuai dengan kode moral kelompok sosial, yang dikendalikan oleh konsep moral. Yang dimaksud dengan konsep moral ialah peraturan perilaku yang telah menjadi kebiasaan bagi angota suatu 
budaya. Konsep moral inilah yang menentukan pola perilaku yang diharapkan dari seluruh anggota kelompok.

Istilah moral sendiri mengarah pada konsep benar salah, baik buruk, sehingga pemaknaan seseorang harus mengarah pada "yang boleh" dan "yang dilarang", serta "yang harus dilakukan" dan "yang tidak pantas dilakukan". Dua konsep yang saling berlawanan tersebut menegaskan pada dualisme moral pada diri manusia. Disatu pihak berkeinginan pada hal-hal yang bersifat baik dan positif dan dilain pihak memiliki kecendrungan kearah yang buruk dan negatif. Untuk itu agar dapat melakukan pemaknaan pada hal-hal yang baik secara lebih mendalam dalam batin seseorang harus ada kesadaran moral (Tafsir, 2002).

Menurut Piaget hakikat moralitas adalah kecenderungan menerima dan menaati sistem peraturan. Selanjutnya, Kohlberg mengemukakan bahwa aspek moral adalah sesuatu yang tidak dibawa dari lahir, tetapi sesuatu yang berkembang dan dapat diperkembangkan/dipelajari. Perkembangan moral merupakan proses internalisasi nilai/norma masyarakat sesuai dengan kematangan dan kemampuan seseorang dalam menyesuaikan diri terhadap aturan yang berlaku dalam kehidupannya. Jadi, perkembangan moral mencakup aspek kognitif yaitu pengetahuan tentang baik/buruk atau benar/salah, dan aspek afektif yaitu sikap perilaku moral mengenai bagaimana cara pengetahuan moral itu dipraktekan.

Disamping perilaku moral, ada juga perilaku tak bermoral yaitu perilaku yang tidak sesuai dengan harapan sosial karena sikap tidak setuju dengan standar sosial yang berlaku atau kurang adanya perasaan wajib menyesuaikan diri; serta perilaku amoral atau nonmoral yaitu perilaku yang tidak sesuai dengan harapan sosial karena ketidakacuhan atau pelanggaran terhadap standar kelompok sosial (Zakiah Derajat, 1997).

Sikap adalah perilaku yang berisi pendapat tentang sesuatu. Dalam sikap positif tersirat sistem nilai yang dipercayai atau diyakini kebenarannya. Nilai adalah suatu yang diyakini, dipercaya, dan dirasakan serta diwujudkan dalam sikap atau perilaku. Biasanya, nilai bermuatan pengalaman emosional masa lalu yang mewarnai cita-cita seseorang, kelompok atau masyarakat. Moral merupakan wujud absrak dari nilai- 
nilai, dan tampil secara nyata/konkret dalam perilaku terbuka yang dapat diamati. Sikap moral muncul dalam praktek moral dengan kategori positif/menerima, netral, atau negatif/menolak.

Anak yang bersikap positif atau menerima nilai-nilai moral, diekspresikan dalam perilaku yang bersimpati dalam berinteraksi dengan nilai dan orang di sekitarnya, seperti mau menerima, mendukung, peduli, dan berpartisipasi dalam kegiatan kelompok. Sikap moral yang netral diekspresikan dalam perilaku sikap tidak memihak (mendukung atau menolak) terhadap nilai yang ada di masyarakat. Sikap moral yang negatif diekspresikan dalam perilaku menolak yang diwarnai emosi dan sikap negatif seperti kecewa, kesal, marah, benci, bermusuhan, dan menentang, terhadap nilai moral yang ada di masyarakat (Syaiful Bahri Zajamarah, 2005).

Pada sikap dan perilaku moral tersirat nilai-nilai yang dianut berkaitan dengan nilai mengenai sesuatu yang dikatakan baik dan benar, patut, dan seharusnya terjadi. Sikap moral sebagian besar diteruskan dari generasi ke generasi melalui proses pendidikan seumur hidup. Ada nilainilai yang perlu dipertahankan, ada yang diasimilasi ke arah kemajuan atau perubahan progresif, tetapi ada juga yang berubah atau bergeser karena berbagai faktor yang mempengaruhinya. Sebagai guru, Anda perlu memahami perkembangan sikap moral agar dapat membantu peserta didik mengembangkan sikap moral yang dikehendaki, mendidik peserta didik menjadi anak yang baik, dan bersikap moral secara baik dan benar.

\section{Etika Moral dan Akhlak}

Etika adalah suatu ilmu yang mengkaji tentang persoalan baik dan buruk berdasarkan akal pikiran manusia. (Daud Ali, 2008) Sedangkan moral adalah suatu hal yang berkenaan dengan baik dan buruk dengan ukuran tradisi dan budaya yang dimiliki seseorang atau sekelompok orang. Berbeda dengan etika dan moral, akhlak adalah bagian yang membicarakan masalah baik dan buruk dengan ukuran wahyu atau al Qur'an dan hadits.

Persoalan baik (al husnu) dan buruk (al khutb) telah menjadi perdebatan sejak era awal kebangkitan Islam. (Kahar, tt) Pada era itu kaum Mu'tazilah berpandangan bahwa ukuran baik dan buruk adalah ditentukan 
oleh akal manusia. Manusia memiliki kualitas akal yang menyebabkannya mampu bahkan menentukan mana yang baik dan mana yang buruk. Berbeda dengan aliran Mu'tazilah, aliran Ahlu Sunnah berpandangan bahwa ukuran tentang al husnu dan al khutb adalah ditentukan oleh wahyu, bukan oleh akal atau rasio manusia. Memang Allah telah mengkaruniai manusia dengan kualitas akal, akan tetapi akal tersebut terbatas hanya mampumengenal hal-hal yang kongkrit, sesuatu yang bisa dinalar (rasional) (Rosihan Anwar, 2008).

Masalah perbuatan baik dan buruk, terpuji dan tercela adalah wilayah kajian akhlak. Akhlak merupakan barometer yang menyebabkan seseorang mulia dalam pandangan Allah dan manusia. Akhlak adalah sikap atau prilaku baik dan buruk yang dilakukan secara berulang-ulang dan diperankan oleh seseorang tanpa disengaja atau melakukan pertimbangan terlebih dahulu. Akhlak yang terpuji dinamakan akhlak al karimah (akhlak mahmudah). Sedangkan akhlak buruk atau tercela dinamakan akhlak mazmumah. Seseorang akan berakhlak baik atau sebaliknya karena dipengaruhi oleh hati (al qalb) yang ada pada sanubari yang terdalam. Artinya, bahwa perbuatan baik atau buruk dalam kategori akhlak bukan didasarkan kepada pertimbangan akal, tradisi atau pengalaman, tetapi karena bisikan hati sanubari yang ada pada setiap orang itu (Ali Daud, 2002).

Manusia yang berakhlak adalah manusia yang suci dan sehat hatinya. Sebaliknya, manusia yang tidak berakhlak (a moral) adalah manusia yang kotor dan sakit hatinya. Dalam hidup dan kehidupan ini, banyak orang mengetahui dan menyadari bila hatinya kotor dan sakit, akan tetapi tidak berhasrat membersih dan mengobatinya dengan segera. Berbeda dengan kotor dan sakit fisik, maka dengan segera mengobati dan membersihkannya. Padahal kalau disadari bahwa penyakit hati itu jauh lebih berbahaya bagi diri dan kelangsungan hidupnya, maka pasti akan memprioritaskan pengobatan hati disbanding dengan pengobatan jasd atau fisik yang hanya bersifat fana.seseorang yang mengalami sakit dalam arti fisik, kalau tidak segera diobati maka akan bertambah parah dan akan mati. Mati bukanlah akhir dari segalanya, tetapi merupakan pintu dari kehidupan selanjutnya. 
Berbeda dengan orang yang mengalami penyakit hati, kalau tidak dibersihkan dan diobati, maka malapetaka yang diakibatkannya bukan hanya di dunia, tetapi bahkan sampai hari akhirat yang abadi. Oleh karena itu upaya untuk membersihkan, memelihara, mencegah dan mengobati agar hati tetap senantiasa sehat, bersih dalam arti berakhlak mulia senantiasa merupakan suatu keniscayaan yang prioritas (Muhammad Azmi, 2006).

Dari uraian di atas dapat dipahami bahwa akhlak berbeda dengan etika dan moral. Kalau akhlak lebih bersifat transcendental karena berasal dan bersumber dari Allah, maka etika dan moral bersifat relatif, dinamis, dan nisbi karena merupakan pemahaman dan pemaknaan manusia melalui elaborasi ijtihadnya terhadap persoalan baik dan buruk demi kesejahteraan hidup manusia di dunia dan kebahagiaan hidup di akhirat. Berdasarkan perbedaan sumber ini maka etika dan moral senantiasa bersifat dinamis, berobah-obah sesuai dengan perkembangan kondisi, situasi dan tuntutan manusia. Etika sebagai aturan baik dan buruk yang ditentukan oleh akal pikiran manusia bertujuan untuk menciptakan keharmonisan.

Begitu juga moral sebagai aturan baik buruk yang didasarkan kepada tradisi, adat budaya yang dianut oleh sekelompok masyarakat juga bertujuan untuk terciptanya keselarasan hidup manusia. Etika, moral dan akhlak merupakan salah satu cara untuk menciptakan keharmonisan dalam hubungan antara sesama manusia (habl minannas) dan hubungan vertikal dengan khaliq (habl minallah) (Muhammad Azmi, 2006).

\section{METODOLOGI PENELITIAN}

Jenis penelitian yang digunakan dalam penulisan ini adalah penelitan kepustakaan (Library Research), yaitu serangkaian penelitian yang berkenaan dengan metode pengumpulan data pustaka, atau penelitian yang digali melalui beragam informasi kepustakaan seperti buku, ensiklopedi, jurnal ilmiah, koran, majalah, penelitian terdahulu dan dokumen (Nana Syaodih, 2009). Penelusuran pustaka ini dibatasi pada pembahasan tertentu dalam rangka untuk memperoleh data penelitian. fokus riset pustaka ini yaitu pada pengkajian dan analisis terhadap berbagai literatur yang memiliki hubungan dengan tema penelitian dan 
diakhiri dengan penarikan kesimpulan sebagai hasil temuan dalam penelitian.

\section{PEMBAHASAN}

\section{Perkembangan Moral Anak Usia Sekolah Dasar}

Dalam mempelajari perkembangan sikap moral peserta didik usia sekolah, Piaget mengemukakan tiga tahap perkembangan moral sesuai dengan kajiannya pada aturan dalam permainan anak.

a. Fase absolut, di mana anak menghayati peraturan sebagai sesuatu hal yang mutlak, tidak dapat diubah, karena berasal dari otoritas yang dihormati (orang tua, guru, anak yang lebih berkuasa).

b. Fase realistis, di mana anak menyesuaikan diri untuk menghindari penolakan orang lain. Dalam permainan, anak menaati aturan yang disepakati bersama sebagai suatu kenyataan/realitas yang dapat diubah asal disetujui bersama.

c. Fase subjektif, di mana anak memperhatikan motif atau kesengajaan dalam penilaian perilaku, anak menaati aturan agar terhindar dari hukuman, kemudian memahami aturan dan gembira mengembangkan serta menerapkannya (Budi Istanto, 2007).

Dalam teori perkembangan moralnya, Kohlberg mengemukakan tiga tingkat dengan enam tahap perkembangan moral.

a. Tingkat 1: Prakonvensional. Pada tingkat ini aturan berisi ukuran moral yang dibuat berdasarkan otoritas. Anak tidak melanggar aturan moral karena takut ancaman atau hukuman dari otoritas. Tingkat ini dibagi menjadi dua tahap. Pertama, tahap orientasi terhadap kepatuhan dan hukuman. Pada tahap ini anak hanya mengetahui bahwa aturan-aturan itu ditentukan oleh adanya kekuasaan yang tidak bisa diganggu gugat. Anak harus menurut, atau kalau tidak, akan mendapat hukuman. Kedua, tahap relativistik hedonisme. Pada tahap ini anak tidak lagi secara mutlak tergantung pada aturan yang berada di luar dirinya yang ditentukan orang lain yang memiliki otoritas. Anak mulai sadar bahwa setiap kejadian mempunyai beberapa segi yang bergantung pada kebutuhan (relativisme) dan kesenangan seseorang (hedonisme). 
b. Tingkat II: Konvensional. Pada tingkatan ini anak mematuhi aturan yang dibuat bersama agar diterima dalam kelompoknya. Tingkat ini juga terdiri dari dua tahap. Pertama, tahap orientasi mengenai anak yang baik. Pada tahap ini anak mulai memperlihatkan orientasi perbuatan yang dapat dinilai baik atau tidak baik oleh orang lain atau masyarakat. Sesuatu dikatakan baik dan benar apabila sikap dan perilakunya dapat diterima orang lain atau masyarakat. Kedua, tahap mempertahan-kan norma sosial dan otoritas. Pada tahap ini anak menunjukkan perbuatan baik dan benar bukan hanya agar dapat diterima oleh lingkungan masyarakat sekitarnya, tetapi juga bertujuan agar dapat ikut mempertahankan aturan dan norma/nilai sosial yang ada sebagai kewajiban dan tanggung jawab moral untuk melaksanakan aturan yang ada.

c. Tingkat III: Pasca-konvensional. Pada tingkat ini anak mematuhi aturan untuk menghindari hukuman kata hatinya. Tingkat ini juga terdiri dari dua tahap. Pertama, tahap orientasi terhadap perjanjian antara dirinya dengan lingkungan sosial. Pada tahap ini ada hubungan timbal balik antara dirinya dengan lingkungan sosial dan masyarakat. Seseorang mentaati aturan sebagai kewajiban dan tanggung jawab dirinya dalam menjaga keserasian hidup bermasyarakat. Kedua, tahap universal. Pada tahap ini selain ada norma pribadi yang bersifat subjektif, ada juga norma etik (baik/buruk, benar/salah) yang bersifat universal sebagai sumber menentukan sesuatu perbuatan yang berhubungan dengan moralitas (Gunarsa, 1985).

Teori perkembangan moral yang dikemukakan Kohlberg seperti halnya Piaget menunjukkan bahwa sikap dan perilaku moral bukan hasil sosialisasi atau pelajaran yang diperoleh dari kebiasaan yang berhubungan dengan nilai kebudayaan semata-mata. Tetapi juga terjadi sebagai akibat dari aktivitas spontan yang dipelajari dan berkembang melalui interaksi sosial anak dengan lingkungannya.

Selain teori perkembangan moral, dalam mempelajari pola perkembangan moral yang berkaitan dengan ketaatan akan suatu aturan yang berlaku universal, perlu dibahas mengenai disiplin. Disiplin berasal dari kata "disciple" yang berarti seorang yang belajar dari/atau secara 
sukarela mengikuti seorang pemimpin. Disiplin diperlukan untuk membentuk perilaku yang sesuai dengan aturan dan peran yang ditetapkan dalam kelompok budaya tempat orang tersebut menjalani kehidupannya. Melalui disiplin, anak belajar untuk bersikap dan berperilaku yang baik seperti yang diharapkan oleh masyarakat lingkungannya. Disiplin dapat ditanamkan secara otoriter melalui pengendalian perilaku dengan menggunakan hukuman, secara permisif/laissezfaire melalui kebebasan yang diberikan kepada anak tanpa adanya hukuman, atau secara demokratis melalui penjelasan, diskusi, dan penalaran mengenai aturan yang berlaku (Habibah dkk, 2007).

Unsur yang berkaitan dengan disiplin adalah sebagai berikut :

a. Peraturan sebagai pola yang ditetapkan untuk perilaku di mana anak hidup, mempunyai nilai pendidikan tentang arah yang harus diikuti dan ditaati anak, dan juga membantu mengekang perilaku yang tidak diinginkan.

b. Hukuman diberlakukan apabila anak melakukan kesalahan ataupun bertindak yang tidak sesuai dengan nilai/norma yang berlaku dalam masyarakat. Hukuman dapat menghalangi anak untuk tidak mengulangi perbuatan yang tidak diinginkan, mendidik anak untuk belajar dari pengalaman, dan memotivasi anak untuk menghindari perilaku yang tidak diterima oleh masyarakat.

c. Penghargaan diberikan apabila anak melakukan sesuatu yang sesuai dengan norma/nilai yang berlaku, mendidik dan memotivasi anak untuk mengulangi perilaku yang baik dan benar sesuai harapan masyarakat.

Konsistensi atau keajegan dalam melaksanakan aturan dan disiplin sehingga tidak membingungkan anak dalam mempelajari sesuatu yang benar/salah atau baik/buruk. Disiplin bermanfaat apabila ada pengaruh disiplin terhadap perilaku, menimbulkan kepekaan akan sikap perilaku yang baik, benar, dan adil, serta mempengaruhi kepribadian anak di mana sikap perilaku disiplin merupakan bagian yang terinternali-sasi pada anak secara keseluruhan (Parjono, 2005). 


\section{Faktor dan Cara Mempelajari Sikap Moral Anak}

Menurut Hurlock Ada sejumlah faktor penting yang mempengaruhi perkembangan moral anak diantaranya adalah sebagai berikut :

a. Peran hati nurani atau kemampuan untuk mengetahui apa yang benar dan salah apabila anak dihadapkan pada situasi yang memerlukan pengambilan keputusan atas tindakan yang harus dilakukan.

b. Peran rasa bersalah dan rasa malu apabila bersikap dan berperilaku tidak seperti yang diharapkan dan melanggar aturan.

c. Peran interaksi sosial dalam memberi kesempatan pada anak untuk mempelajari dan menerapkan standar perilaku yang disetujui dalam masyarakat, keluarga, sekolah, dan dalam pergaulan dengan orang lain (Sinolungan, 1997).

Sikap dan perilaku moral dapat dipelajari dengan cara berikut :

a. Belajar melalui coba-ralat (trial and error). Anak mencoba belajar mengetahui apakah perilakunya sudah memenuhi standar sosial dan persetujuan sosial atau belum. Bila belum, maka anak dapat mencoba lagi sampai suatu ketika secara kebetulan dapat berperilaku sesuai dengan yang diharapkan.

b. Pendidikan langsung yang dilakukan dengan cara anak belajar memberi reaksi tertentu secara tepat dalam situasi tertentu, serta dilakukan dengan cara mematuhi peraturan yang berlaku dalam keluarga, sekolah, maupun masyarakat sekitar.

c. Identifkasi dengan orang yang dikaguminya. Cara ini biasanya dilakukan secara tidak sadar dan tanpa tekanan dari orang lain. Yang penting ada teladan dari orang yang diidentifikasikan untuk ditiru perilakunya (Sinolungan, 1997).

Pendidikan saat ini umumnya mempersiapkan peserta didik memiliki banyak pengetahuan, tetapi tidak tahu cara memecahkan masalah tertentu yang dihadapi dalam kehidupan bermasyarakat seharihari. Pendidikan lebih mempersiapkan peserta didik untuk menjadi anak yang pandai dan cerdas, tetapi kurang mempersiapkan peserta didik untuk menjadi anak yang baik. Masalah berkenaan dengan baik dan buruk menjadi kajian bidang moral. Demikian juga dalam mengembangkan 
aspek moral peserta didik berarti bagaimana cara membantu peserta didik untuk menjadi anak yang baik, yang mengetahui dan berperilaku atau bersikap berbuat yang baik dan benar. Sikap dan perilaku moral dapat dikembangkan melalui pendidikan dan penanaman nilai/norma yang dilakukan secara terintegrasi dalam pelajaran maupun kegiatan yang dilakukan anak di keluarga dan sekolah. Pendidikan bukan hanya mempesiapkan anak menjadi manusia cerdas, tetapi juga menjadi manusia yang baik, berbudi luhur, dan berguna bagi orang lain (Sukmadinata, 2003).

\section{Pentingnya Pendidikan Moral Bagi Anak SD/MI}

Di sekolah Dasar, barangkali tidak pernah sebelumnya atau sesudahnya dengan asumsi keadilan lingkungan dan keluarganya menguntungkan anak menjadi moral yang sangat dahsyat, yang sangat berminat memikirkan alasan-alasan dunia ini; bagaimana dan mengapa semua hal di dunia ini berlangsung. Juga, bagaimana dan mengapa semua ia harus berprilaku dalam berbagai macam situasi. "ini merupakan masa suara hati", begitu Anna Freud pernah mengamati, dan ia mengatakan lebih jauh: "Inilah masa dimana kata hati seorang anak dibentuk atau tidak dibentuk; inilah masa dimana ketika watak anak dibentuk dan dimantapkan". Ini merupakan tahun-tahun dimana sebuah dunia baru, yang berisi pengetahuan dan kemungkinan berdatangan dalam bentuk buku, musik, kesenian, atletik. Dan tentu saja, para guru dan pelatih menawarkan semuanya ini serta sesama murid yang saling berbagi pengalaman dengan mereka, masuk kedalam kehidupan mereka. Ini merupakan tahun-tahun keajaiban, tahun-tahun imajinasi yang bergolak dan diberi umpan dengan cara yang tak terbilang banyaknya, tahun-tahun segala sesuatu yang berkaitan dengan sebuah pikiran yang didorong untuk menjajaki dunia, untuk mencobab memahaminya. Ini merupakan tahuntahun pencarian yang hidup dan penuh semangat bagi anak-anak, yang orang tua dan gurunya seringkali kesulitan mengimbanginya sewaktu mereka berusaha memahami segala sesuatunya, memikirkannya, dan juga menimbang-nimbang mana yang benar dan yang salah dari hidup ini. Inilah saat perubahan imajinasi moral yang terus menerus diberi bahan bakar dengan kerelaan, kesediaan anak-anak untuk menempatkan diri 
mereka sendiri dalam peran orang lain, untuk menyelami jalan kehidupan mereka (Robert Coles, 2003).

Pendidikan Moral penting untuk dipelajari dan dapat mulai membangunnya saat anak masih dalam usia balita. Meski pada usia tersebut mereka belum mempunyai kemampuan kognitif untuk melakukan penalaran moral yang cukup kompleks, pada saat itulah dasardasar kebiasaan moral seperti melatih kontrol diri, bersikap adil, menunjukan rasa hormat, berbagi dan berempati mulai dipelajari.

Kecerdasan moral terbangun dari tujuh kebajikan utama yakni Empati, hati nurani, kontrol diri, rasa hormat, kebaikan hati, toleransi, dan keadilan. Yang membantu anak menghadapi tantangan dan tekanan etika yang tidak dapat dihindarkan dalam kehidupan kelak. Kebajikankebajikan utama tersebutlah yang akan melindunginya agar tetap berada dijalan yang benar dan membantunya agar selalu bermoral dalam bertindak. Semua itu dapat diajarkan, dicontohkan, disadarkan, serta didorong sehingga dapat dicapai anak. Berikut adalah tujuh kebajikan utama yang akan menjaga sikap baik seumur hidup anak (Michele Borba, 2008).

1. Empati, Merupakan inti emosi moral yang membantu anak memahami perasaan orang lain. Kebajikan ini membantunya menjadi peka terhadap kebutuhan dan perasaan orang lain, mendorongnya menolong orang yang kesusahan atau kesakitan, serta menuntutnya memperlakukan orang dengan kasih sayang. Emosi moral yang kuat mendorong anak bertindak benar karena ia bisa melihat kesusahan orang lain sehingga mencegahnya melakukan tindakan yang dapat melukai orang lain.

2. Hati Nurani, adalah suara hati yang membantu anak memilih jalan yang benar dari pada jalan yang salah serta tetap berada dijalur yang bermoral, membuat dirinya merasa bersalah ketika menyimpang dari jalur yang semestinya. Kebajikan ini membentengi anak dari pengaruh buruk dan membuatnya mampu bertindak benar meski tergoda untuk melakukan hal yang sebaliknya. Kebajikan ini merupakan fondasi bagi perkembangan sifat jujur, tanggung jawab, dan integritas diri yang tinggi. 
3. Kontrol Diri, membantu anak menahan dorongan dari dalam dirinya dan berpikir sebelum bertindak, sehingga ia melakukan hal yang benar, dan kecil kemungkinan mengambil tindakan yang akan menimbulkan akibat buruk. Kebajikan ini membantu anak menjadi mandiri karena ia tahu bahwa dirinya bisa mengendalikan tindakannya sendiri. Sikap ini membangkitkan sikap murah dan baik hati karena anak mampu menyingkirkan keinginan memuaskan diri serta merangsang kesadaran mementingkan keperluan orang lain.

4. Rasa Hormat, mendorong anak bersikap baik dan menghormati orang lain. Kebajikan ini mengarahkan anak memperlakukan orang lain sebagaimanan ia ingin orang lain memperlakukan dirinya, sehingga mencegah anak bertindak kasar, tidak adil, dan bersikap memusuhi, jika anak terbiasa bersikap hormat terhadap orang lain, ia akan memperhatikan hak-hak serta perasaan orang lain; akibatnya, ia juga akan menghormati dirinya sendiri.

5. Kebaikan Hati, membantu anak menunjukan kepeduliannya terhadap kesejahteraan dan perasaan orang lain. Dengan mengembangkan kebajikan ini, anak lebih belas kasih dan tidak terlalu memikirkan diri sendiri, serta menyadari perbuatan baik sebagai tindakan yang benar. Kebaikan hati membuat anak lebih banyak memikirkan kebutuhan orang lain, menunjukan kepedulian, memberi bantuan kepada yang memerlukan, serta melindungi mereka yang kesulitan atau kesakitan.

6. Toleransi, membuat anak mampu menghargai perbedaan kualitas dalam diri orang lain, membuka diri terhadap pandangan dan keyakinan baru, dan menghargai orang lain tanpa membedakan suku, gender, penampilan, budaya, kepercayaan, kemampuan, atau orientasi seksual. Kebajikan ini membuat anak memperlakukan orang lain dengan baik dan penuh pengertian, menentang permusuhan, kekejaman, kefanatikan, serta menghargai orang-orang berdasarkan karakter mereka.

7. Keadilan, menuntun anak agar memperlakukan orang lain dengan baik, tidak memihak, dan adil, sehingga ia mematuhi aturan, mau bergiliran dan berbagi, serta mendengar semua pihak secara terbuka sebelum memberi penilaian apapun. Karena kebajikan ini meningkatkan 
kepekaan moral anak, ia pun akan terdorong membela pihak yang diperlakukan secara tidak adil dan menuntut agar semua orang tanpa pandang suku, bangsa, budaya, status ekonomi, kemampuan, atau keyakinan diperlakukan setara (Michele Borba, 2008).

\section{SIMPULAN}

Dari uraian pembahasan diatas dapat disimpulkan bahwa Moral berarti perilaku yang sesuai dengan peraturan perilaku mengenai baik/buruk, benar/salah yang telah menjadi kebiasaan dan harapan suatu masyarakat. Mempelajari perkembangan moral bermanfaat untuk membantu peserta didik mengembangkan sikap moral yang dikehendaki, serta mendidiknya menjadi anak yang baik dan bersikap moral baik dan benar.

Perkembangan moral menurut Kohlberg ada tiga tingkat dengan enam tahap yaitu tingkat praoperasional dengan tahap orientasi pada kepatuhan/hukuman dan relativistik, tahap konvensional dengan tahap orientasi mengenai anak baik dan mempertahankan norma sosial/otoritas, serta tingkat paska konvensional dengan tahap orientasi perjanjian diri dengan lingkungan dan tahap universal. Faktor yang mempengarahi perkembangan moral antara lain: peran hati nurani, peran rasa malu dan bersalah, peran interaksi sosial. Sikap dan perilaku moral dapat dipelajari dengan cara coba dan ralat, pendidikan langsung, identifikasi.

Sebagai orang tua dan guru, tidak bisa hanya duduk dan berharap agar anak-anak menjadi manusia yang penyayang dan baik hati. Terlalu banyak pengaruh lingkungan berbahaya bagi perkembangan moral anak. Namun, ada jalan keluar bagi kekhawatiran kita tersebut, yaitu apa yang dikatakan oleh para peneliti: kita bisa mengubah hidup anak kita karena tujuh kebajikan utama yang membangun kecerdasan moral itu bisa dipelajari dan kita bisa mengajarkannya. Mengajarkan kebajikan tersebut secara terus menerus baik dirumah, di sekolah, maupun dilingkungan masyarakat kita merupakan cara terbaik membimbing anak menjadi baik dan bermoral. Antara akhlak, etika dan moral, memiliki persamaan dan perbedaan. Persamaannya adalah sama-sama mengkaji masalah baik dan buruk, sedangkan perbedaanya adalah terletak pada landasan yang dipakai. 


\section{DAFTAR PUSTAKA}

Ali Daud. 2002. Pendidikan Agama Islam, Jakarta, Raja Grafindo Persada.

Budi Istanto. 2007. Pentingnya Pendidikan Moral Bagi Generasi Penerus, Ypgyakarta, FIP UNY.

Gunarsa. 1985. Dasar dan Teori Perkembangan Anak, Jakarta, BPK Gunung Mulia.

Habibah dkk. 2007. Metode Pengembangan Moral Anak Pra Sekolah, Yogyakarta, FIP UNY.

Michele Borba. 2008. Membangun Kecerdasan Moral, Jakarta, Gramedia Pustaka Utama.

Muhammad Azmi. 2006. Pembinaan Akhlak Anak Pra Sekolah:Upaya Mengefektifkan Nilai-nilai Pendidikan Islam Dalam Keluarga, Yogyakarta, Belukar.

Nana Syaodih. 2009. Metode Penelitian Pendidikan, Bandung, PT Remaja Rosdakarya.

Parjono. 2005. Pendidikan Nilai-nilai Moral, Yogyakarta, MKU UNY.

Robert Coles. 2003. Menumbuhkan Kecerdasan Moral Pada Anak, Jakarta, Gramedia Pustaka Utama.

Rosihan Anwar. 2008. Aqidah Akhlak, Bandung, Pustaka Setia.

Sukmadinata. 2003. Landasan Psikologi Proses Pendidikan, Bandung, Rosdakarya.

Sinolungan. 1997. Psikologi Perkembangan Peserta Didik, Jakarta, Gunung Agung.

Syaiful Bahri Djamarah. 2005. Guru dan Anak Didik Dalam Interaksi Edukatif: Suatu Pendekatan Teoritis Psikologis, Jakarta, Rineka Cipta.

Tafsir. 2002. Moralitas Al-Qur'an dan Tantangan Modernitas, Yogyakarta, Gama Media.

Zakiah Derajat. 1997. Membina Nilai-nilai Moral di Indonesia, Jakarta, Bulan Bintang. 